\title{
Lexicography on an epic scale: Robert Burchfield, 1923-2004
}

\author{
TOM MCARTHUR
}

THE WORLD-RENOWNED Oxford lexicographer Robert William Burchfield is a hero of mine who, to my great good fortune, became first a colleague then a friend, as he also was to ET.

He was born on 27 January 1923 in Wanganui, North Island, New Zealand, and died on the 5th of July 2004 at the age of 81, in Oxfordshire in England. I never worked with him directly in lexicography, but when I was editing the Oxford Companion to the English Language he contributed a set of entries relating to both Oxford University Press and its lexicography, including entries on the famous (or infamous) H. W. (Henry Watson) Fowler and his brother F. G. (Francis George), who created both the decades-long bestseller The King's English (1906) and the first edition of the Concise Oxford Dictionary (1911). His entries also included New Zealand English, which was written in tandem with his fellow Kiwi, Laurie J. Bauer, and Bob and I shared the entry Oxford English Dictionary, in the creation of which I happily played second fiddle.

He received the first stage of his higher education at Victoria University College in Wellington, NZ, then served for much of the Second World War in the Royal New Zealand Artillery (1941-46). The Associated Press obituary notes that 'while working in Trieste, Italy, he was taken with a copy of Lancelot Hogben's "Loom of Language"" (as in the Los Angeles Times, 7 July), a classic commentary that apparently helped crystallize his interest in English. Indeed, it is often in such random ways that batons are passed from generation to generation. When the war ended, he finished his studies in Wellington, and in 1949 went to Oxford as a Rhodes Scholar. Among his teachers there, with what one might call 'mythic' good luck, were J. R. R. Tolkien (Master of
Middle Earth) and C. S. Lewis (Master of Magic Wardrobes and Silent Planets).

Not long afterwards, he became a lecturer in English at Christ Church (1953-57) then a lecturer and later first a Tutorial Fellow (1963-) then a Senior Research Fellow (1979-) of St Peter's College, of which after his retirement he became an Emeritus Fellow (1990-). This rather dry progression, however, although entirely typical of and appropriate to Oxford and other universities, provides no inkling of the key development in his career, which began in 1957, when he became the editor of a new Supplement to the Oxford English Dictionary. At that point, the OED project was c. 115 years old, a vast labour of love first proposed by Richard Chenevix Trench to the Philological Society in London in 1842, shortly after it was founded. The ever-expanding project was then sustained through the later nineteenth and into the twentieth century by the already venerable press of Oxford University, which dates from at least the 16th century.

In 1957 then, under this new editor, fresh life was breathed into an already vast and venerable project published in 1928; in 12 volumes of 15,487 pages covering 414,825 words backed by 5 million citations, some 2 million of which appear in the dictionary. However, the language had in the meantime moved on almost 30 years, as a consequence of which the project ahead of the new editor was not only to keep on cataloguing words but also, as it transpired, to help create an entire dictionaries department within OUP - duly set up in 1971 . Robert Burchfield then remained chief editor of the Oxford English dictionaries until his retirement in Orwell's year, 1984: that is, 30 further years in the life of the $O E D$.

The creation first of the $O E D$ then its Supplement (as well indeed as OUP's entire dictionary 
compiling and publishing programme) has been the achievement of a succession of giants of lexicography. The line begins in 1957 with the Anglican clergyman Richard Chenevix Trench, who hoped for a comprehensive dictionary of English which would match - and maybe outdo - what some Continentals were beginning to attempt with their languages, notably the Brothers Grimm, Jakob and Wilhelm, with German: Wilhelm however dying before reaching D, and Jakob at F. Their work came to an end around 1960: that is, 142 years after it had begun.

The first editors of the Society's dictionary were Herbert Coleridge and Frederick Furnivall, who dug its foundations by researching source materials and applying the principles of comparative philology to the project. After them came the first hands-on editor, James Augustus Henry Murray, an erudite Scot, a schoolmaster in London at the time he was appointed. In later years Murray was assisted, then followed by three further editors, the Englishmen Henry Bradley and C. T. Onions, and fellow Scot William Alexander Craigie. Bradley and Onions completed the 12-volume dictionary in 1928, then brought out a supplement in 1933. After that, however, the project went into suspension for a quarter of a century, until Burchfield began a fuller supplement that became the Supplement. However, as he wryly noted in our Companion entry:

This work followed the pattern of the original in taking approximately four times as long to compile as the initial forecasts suggested, and ending up as four volumes instead of the one proposed volume of 1,275 pages.

A key feature of Burchfield's Supplement is, as he put it, that 'it reached out to the vocabulary of all parts of the English-speaking world,' giving roughly equal treatment to lexis in the UK, the US, Canada, Australia, New Zealand, and elsewhere. The volume A-G was published in $1972, \mathrm{H}-\mathrm{N}$ in 1976, O-Scz in 1982, and Se-Z in 1986. Lexicography of this kind operates on an epic scale: in effect, matching in language terms the literary significance of Homer, Virgil, Dante, and Shakespeare. And this epic continues. Work on a Second Edition of the entire $O E D$ began in 1983, after which the OED and other OUP lexicographical and encyclopaedic projects began to move into the brave new world of computers. In the almost unimaginably vast and complex work of the $O E D$, Bob's admirable successors, John Simpson and Edmund Weiner, have been co-editors ever since.

In the course of his work and later, Robert Burchfield received many honours, among them President of the English Association, Honorary Fellow of the Institute of Linguists, honorary foreign member of the American Academy of Arts and Sciences, and honorary doctor in Victoria University, his New Zealand alma mater.

Where I felt closest to him, in both academic and professional terms, was a sense of the phenomenon that in the ' 80 s became increasingly known by such labels as world English, international English, and (world) Englishes, and in the '90s global English. As I perceived it then and still see it, Bob's greatest gift to the Press and the world was his move (as a New Zealander with a non-northern-hemisphere perspective) away from both the 'sceptred isle' approach (Mother England knows best and her upper echelons speak the best) and a combined approach in which Uncle Sam and Britannia both know best (in rather different ways), into a sense of shared possession throughout the vast complex that goes by the name of English. Of course the United States now dominates English and the United Kingdom still manages to make waves (even if it no longer rules them), but nowadays even the primacy of native speakers and their avowed intuitions are being challenged, and all the world is now free to add to the word hoard of the language.

For me, one of the finest of the many achievements of OED and Supplement which the next edition will incorporate and expand is the etymologies. These constantly remind us of how many other languages this language has drawn on and still draws on, a matter that is just as important as how many other languages have drawn, and still draw, on it. Robert Burchfield was a key link in a unique chain, whose current links in Oxford and elsewhere should be even more fully recognised internationally than they currently are. In the quiet, steady tradition of OUP's historical lexicography they continue to be pioneers, at the cutting edge of things. That is how Bob Burchfield and his predecessors would have wanted it, even though none of those earlier predecessors could have begun to imagine the global techno-culture whose words (tidily sorted and annotated) are now being added to the pile. 